\title{
Water, Sanitation and Hygiene Behaviours, and the Oral Health Status of School- Going Adolescent Boys and Young Men in Kampala, Uganda
}

\author{
Tonny Ssekamatte ( $\nabla$ tssekamatte@musph.ac.ug) \\ Makerere University School of Public Health \\ Joseph KB Matovu \\ Makerere University School of Public Health \\ Steven Ndugwa Kabwama \\ Makerere University School of Public Health \\ John Ssenkusu \\ Makerere University School of Public Health \\ Rhoda K. Wanyenze \\ Makerere University School of Public Health
}

\section{Research Article}

Keywords: Adolescent boys and young men, hand hygiene, sanitation, oral health

Posted Date: January 24th, 2022

DOI: https://doi.org/10.21203/rs.3.rs-1237394/v1

License: (c) (1) This work is licensed under a Creative Commons Attribution 4.0 International License. Read Full License 


\section{Abstract \\ Background}

Universal access to safe drinking water, sanitation and hygiene services is an essential component of keeping young people in school. However, much of the focus has been directed towards meeting the sanitation and hygiene needs of school-going adolescent girls and young women with limited attention to their male school-going counterparts. We determined the oral health status and good hand hygiene practices and the factors associated with good hand hygiene practices among adolescent boys and young men (ABYM) in Kampala, Uganda.

\section{Materials and methods}

This cross-sectional survey was conducted among 1,869 school-going ABYM, who were randomly selected at household level from the five administrative divisions of Kampala, Uganda. A modified Poisson regression model was used to establish the factors associated with good hand hygiene practices (i.e. defined as always washing hands before eating and after visiting the latrine or toilet) among ABYM in Kampala.

\section{Results}

Overall, $81.4 \%(1,522 / 1,869)$ of the respondents had access to a drinking water source at their school. Nonetheless, $56.9 \%(1,064 / 1,869)$ carried water from home to drink while at school. Nearly all $(98.9 \%, 1,849 / 1,869)$ respondents attended in schools that had sex-separated toilets/latrines; $95.6 \%(1,787 / 1,869)$ had safe toilets, while $97.0 \%(1,813 / 1,869)$ had latrines/toilets that provided for privacy. Only $42.5 \%(794 / 1,869)$ exhibited good hand hygiene practices. Good hand hygiene practices were associated with age 18-24 years (adjusted Prevalence Ratio [aPR] = 0.63; 95\% Confidence Interval [95\% Cl]: 0.50, 0.78) and studying from a school with both handwashing and sanitary facilities (aPR=2.67; 95\% Cl: $1.84,3.85)$. Slightly more than a quarter (26.4\%, 495/1,869) of the respondents had at least one cavity in their teeth, $18.7 \%(349 / 1,869)$ had difficulty biting hard foods, $13.3 \%(248 / 1,869)$ had difficulty chewing, $6.0 \%$ $(113 / 1,869)$ avoided laughing because of the appearance of their teeth and $16.1 \%(301 / 1,869)$ missed school in the last 12 months due to a toothache.

\section{Conclusion}

Our study revealed that the majority of the ABYM had access to basic drinking water and sanitation facilities while at school. However, their hand hygiene and oral health practices were sub-optimal. Our findings suggest a need for school authorities to intensify hygiene and oral health education in educational settings.

\section{Background}

Universal access to drinking water, sanitation and hygiene (WASH) as outlined in the 2030 sustainable development goals (SDG) agenda, remains a public health challenge in schools worldwide (Ahmed et al., 2021, United Nations, 2015). The 2030 vision for WASH in schools is enshrined in SDGs 3, 4 and 6. SDG 3 calls upon United Nations (UN) member states to sustainably work towards ending water-borne diseases such as cholera, typhoid and dysentery. SDG 4 calls for universal access to basic drinking water, single-sex basic sanitation, and basic handwashing facilities in schools. Additionally, SDG 6 calls for universal access to safely managed drinking water services, safely managed sanitation services and handwashing facilities with soap and water (United Nations, 2015, UNICEF and WHO, 2020, UNDP, 2021, WHO, 2019, Ahmed et al., 2021). SDGs also call upon UN member states to work towards ending open defecation and to pay special attention to the needs of vulnerable populations such as individuals with limited mobility (UNDP, 2021, Rebelo et al., 2019).

Although several SDGs are specific about WASH, none is explicit about oral health, making it a neglected issue on the global health agenda (Benzian et al., 2021). Yet, oral diseases are one of the major non-communicable diseases affecting over 3.5 billion people (Bernabe et al., 2020). About 10\% of the global population is affected by severe periodontal (gum) disease, which often results in tooth loss (WHO, 2021, Baiju et al., 2019). Besides, there are 530 million cases of dental caries/tooth decay/cavities among children, the majority of whom live in low and middle-income countries (LMCs), where provision of dental services is limited (WHO, 2021, Batwala et al., 2007). The major risk factors for dental carries among children are unhealthy diet high in sugar, use of tobacco, harmful use of alcohol and poor oral hygiene (WHO, 2021, Abbass et al., 2019).

In relation to WASH, only three-quarters of secondary schools (74\%) and two-thirds of primary schools (66\%) globally had a basic water service in 2019 (UNICEF and WHO, 2020). Limited access to a basic drinking water service at school affected 584 million children, among whom, 297 million were in schools that had an improved source with no water available, and 287 million were in schools with no water service (UNICEF and WHO, 2020). Almost half of the children in schools without water service lived in low-income countries. Access to basic sanitation in schools is also a challenge. Overall, $63 \%$ of schools globally had access to a basic sanitation service while $71 \%$ of secondary schools and $60 \%$ of primary schools had a basic sanitation service. Limited access to a basic sanitation service in schools affects 698 million children, among whom 331 million are in schools with improved sanitation facilities that were sexdisaggregated or not usable, and 367 million had no sanitation service at all. Almost a quarter of the children in schools without a sanitation service lived in low-income countries (UNICEF and WHO, 2020). The World Health Organisation (WHO)/United Nations Children's Fund (UNICEF) Joint Monitoring Programme 2019 global estimates indicated that only $57 \%$ of schools had a basic hygiene service while $25 \%$ neither had hand hygiene facilities nor water at the school premises (UNICEF and WHO, 2020). About 40\% of children whose schools had no hygiene service lived in the least developed countries (UNICEF and WHO, 2020). 
There have been commendable efforts by the Ugandan government and implementing partners to improve oral health and WASH behaviours of school-going adolescents and young adults (WHO, 2016, Ministry of education and sports, 2017). For instance, in 2017, the Ugandan Ministry of Education and Sports (MoES) adopted and contextualized the UNICEF three-star approach to stimulate effective WASH behaviours amongst the learners (Ministry of education and sports, 2017). The three-star approach ensures that healthy habits are taught, practised and integrated into daily school routines (UNICEF and GIZ, 2013, Ministry of education and sports, 2017, Wagner and Samuelsson, 2019, Duijster et al., 2020, Mukherjee and Alam, 2017). Besides, MoES and UNICEF developed national WASH standards which require each staff and learner in Uganda to have access to 1.5 litres of safe drinking water per day, and separate toilets for all girls and boys and children with disabilities, with at least one toilet for 40 learners (UNICEF, 2020). Besides, schools are required to provide one hand washing facility with soap and water per 40 learners. Other critical requirements included regular health education on WASH, food safety and hygiene, proper solid waste and excreta and waste water management, and provision of menstrual hygiene facilities (UNICEF, 2020). Similarly, the government of Uganda in collaboration with WHO developed the national oral health policy (2007) to provide a framework for the prevention of oral diseases. The policy emphasizes the need for schools to undertake oral health education, periodic screening of school children and training teachers on oral health education and promotion (Ministry of Health and WHO, 2007). Despite the existence of the different interventions and standards, the status of WASH and oral health in Uganda remains suboptimal. About $87.5 \%$ of primary and $93.5 \%$ of secondary schools have access to basic drinking water, $90 \%$ of primary and $95.5 \%$ of secondary schools have single-sex sanitation facilities, and just $40.9 \%$ of primary and secondary schools have hand hygiene facilities. Only $42 \%$ of learners in Uganda are enrolled in schools with basic handwashing facilities (Government of Uganda, 2020). Data on oral health remains limited.

Improved WASH is a right for every learner as it has enormous benefits (WHO, 2019, Han et al., 2020). Safe drinking water promotes regular hydration which in turn improves the cognitive performance of learners (Masento et al., 2014). Safe and usable WASH infrastructure coupled with good practices reduces the incidence of infectious diseases including COVID-19 (Skolmowska et al., 2020, Yigzaw et al., 2021), and diarrhoeal diseases such as typhoid and dysentery (Taddese et al., 2020, Azhar et al., 2021). Improved WASH behaviours reduce absenteeism from school, health and wellbeing of learners and to uphold the dignity of the learners (WHO, 2019). There is evidence that the WASH behaviours that children learn and practice at school are likely to be the norm in society when they become adults, and that children who practice the desired WASH behaviours are more able to integrate sanitation and hygiene education into their daily lives, and are effective messengers and agents of change within their families and the wider community (Bartram et al., 2009). Besides, access to safe WASH infrastructure is associated with better educational outcomes such as performance and better WASH-related behaviours (Thakadu et al., 2018). Similarly, good oral health alleviates pain, discomfort, disfigurement and even death, and promotes quality of life (Spanemberg et al., 2019).

There has been considerable attention towards WASH in schools both globally and locally (Government of Uganda, 2020, Ministry of Education and Sports, 2021, Sommer et al., 2016, Sommer et al., 2021, Hennegan et al., 2018). However, the focus has been directed towards meeting the sanitation and hygiene needs of adolescent girls and young women, particularly menstrual hygiene management (AGYW), and less attention to the young boys. Adolescent boys and young men (ABYM) have unique oral health, and sanitation and hygiene needs that should be addressed based on their social class, disability, ethnicity and age (Bell et al., 2013, Cavill et al., 2018, Kato-Wallace et al., 2016, Amin et al., 2018, WHO, 2000). Failure to understand the sanitation and hygiene needs and behaviours of $A B Y M$ is likely to negatively impact sanitation and hygiene promotion when they turn into men. Yet, it is reported that men compared to women, often exhibit unfavourable sanitation and hygiene behaviours (Kwiringira et al., 2014). For example, men are less likely to practice hand hygiene during critical moments such as before and after using a toilet, are less likely to use a toilet facility even when available, are harder to engage in sanitation and hygiene promotion activities, and often practice unfavourable sanitation practices such as open urination and defecation (Lopez et al., 2019, Cavill et al., 2018). Unfavourable sanitation and hygiene behaviours of men have been attributed to their desire to slow the rate of pit filling, having more time for open urination and defecation, greater mobility of men, lack of shame about open defecation and lack of toilets at workplaces (Chambers and Myers, 2016, Coffey et al., 2014). The limited focus on the WASH needs and oral health of adolescent boys and young men (ABYM) in educational settings is likely to "leave them behind" during the attainment of the SDGs. It was against this background that we established the WASH behaviours and oral health status of school-going ABYM. Our findings can be used to inform WASH in schools related policies and programmes.

\section{Materials And Methods Study design and setting}

This study was implemented as part of a large cross-sectional study that assessed the health status of adolescent boys and young men in Kampala, Uganda (Matovu et al., 2021a). Study methods have been described previously (Matovu et al., 2021a, Kabwama et al., 2021a). Briefly, the larger cross-sectional study was implemented in the five divisions (i.e. Rubaga, Kawempe, Makindye, Nakawa and Kampala Central) of Kampala, Uganda's capital. Kampala has a total population of 1,507,080 million and 414,406 households (UBOS, 2017). About $15.8 \%(232,628)$ and $27.5 \%$ (403,784) of Kampala's population is aged $10-17$ and $15-24$ years respectively. About $86 \%(176,628)$ of persons aged $6-12$ years attend primary school. About $85.8 \%$ (87,357) of males aged 6-12 years and $86.2 \%(89,271)$ attend primary school. About $55.4 \%(106,905)$ of persons aged $13-18$ years attend secondary school. About $58.8 \%(47,124)$ of males aged $13-$ 18 years and $52.9 \%(59,781)$ attend secondary school (UBOS, 2017). The education levels in Uganda include pre-primary, primary, secondary and postsecondary. The official school going age bracket for pre-primary level is $3-5$ years; 6 - 12 years for primary level, $13-18$ years for secondary level and $19-$ 24 years for post-secondary school level (UBOS, 2016). Prior to this study, the 2015 National Service Delivery Survey had showed that in Kampala, nearly all (98\%) primary and all (100\%) secondary schools had sanitary facilities, $64.1 \%$ of primary and $65.8 \%$ of secondary schools had adequate toilets, all primary and secondary schools had sex-disaggregated toilets, $37.3 \%$ of primary and $40.7 \%$ of secondary schools had toilet facilities that met the needs of learners with limited mobility (UBOS, 2016). About $88.8 \%$ of primary and $94.3 \%$ of secondary schools had separate toilet facilities for teachers, while the pupil stance ratio was 1:75 for girls and 1:70 for boys in primary schools, and 1:81 for girls and 1:89 for boys (UBOS, 2016). Majority (95\%) of primary and all secondary schools had an improved drinking water source. All vocational institutions had sex-disaggregated toilet facilities. Majority (94.5\%) had adequate toilet facilities, $70.6 \%$ had separate toilets for teachers, and $20.9 \%$ had toilet facilities for individuals with limited mobility (UBOS, 2016). This study was conducted at the beginning of the COVID-19 pandemic in Uganda at a time of heightened attention to hygiene to further inform prevention measures among ABYM.

Page 3/16 


\section{Study population and inclusion and exclusion criteria}

The current study was conducted among school-going ABYM in Kampala. ABYM were defined as either boys or men aged 10-24 years (Kato-Wallace et al., 2016). The study included all ABYM who were residing in any of the five divisions of Kampala aged 10-24 years and who were enrolled in school at the time of the study. We excluded all ABYM aged 10-24 years who were very sick and those who were studying from schools outside Kampala. We also excluded ABYM who were not conversant with the local dialect (Luganda) or English.

\section{Sample size and Sampling considerations}

The current study is a sub-analysis of a larger study titled "Perception of Risk, Risk-taking Behaviours and Health Needs of Adolescent Boys and Young Men in Kampala, Uganda" whose detailed sample size estimates and sampling procedure have been published elsewhere (Matovu et al., 2021b, Kabwama et al., 2021b). Briefly, the larger study was conducted among 604 ABYM out-of-school and 1896 school-going ABYM. The current analyses are based on schoolgoing ABYM who were selected from sampled households within the five divisions of Kampala. We used a multi-stage sampling technique to select the respondents. First, we purposely selected $50 \%$ (48) of the total (96) number of wards and then used a random number generator to select $20 \%$ of the cells in the 48 wards. The total number of households per cell was derived from the household lists provided by the local leaders. We used the total number of households per cell to facilitate probability proportionate sampling. Simple random sampling was used to obtain respondents in households where more than one ABYM were eligible.

\section{Data Collection methods, tool and procedure}

Data were collected between July and August 2020 through face to face interviews guided by an electronic mobile-based structured questionnaire. Before data collection, we obtained a list of schools from Kampala Capital City Authority to ensure that all the respondents studied from schools in Kampala. During data collection, respondents were asked whether they were still at school and the schools they attended. After ascertaining the schooling status of the respondents, we used the Global School-based Student Health Survey (GSHS) to obtain data on access to drinking water, sanitation and hygiene behaviours, and oral health. The GSHS is a low-cost WHO validated self-administered questionnaire which is used to obtain data on 10 core modules considered to be the leading causes of morbidity and mortality among children and adults worldwide (Johnson et al., 2019, WHO, 2020). The GSHS is designed to capture data on students between 13-17 years. For purposes of this study, the GSHS was expanded to capture data from ABYM aged groups 10-24 years, and modified to an interviewer-administered questionnaire. The questionnaire also captures data on young people's health behaviour and protective factors. This tool has previously been used to ascertain sanitation and hygiene behaviours of adolescents and young people in schools (World Health Organization, 2018, Johnson et al., 2019, Jatrana et al., 2021b).

\section{Variable measurement}

\section{Dependent variables}

Access to drinking water was established by asking respondents if a drinking water source was available at their school (coded as Yes=1 and No=0), whether they carried water from home to drink while at school (coded as Yes=1 and $\mathrm{No}=0$ ) and the frequency of drinking water from the source at school (coded as $0=$ No drinking water source, $1=$ Never, $2=$ Rarely, $3=$ Sometimes and $4=$ Most of the time). To ascertain access to sanitation facilities, respondents were asked if their school had separate toilets for boys and girls (coded as $0=$ No toilets at school, $1=$ No and $2=Y e s$ ), whether toilets at school were safe (coded as $0=$ No and $1=$ Yes), clean (coded as $0=$ No and $1=Y e s$ ), accessible (coded as $0=$ No and $1=Y e s$ ) and private (coded as $0=$ No and $1=$ Yes). Hand hygiene practice was assessed by asking the respondents about their frequency of handwashing during two of the five critical moments i.e. before eating food and after using a latrine facility. The responses to these questions were coded as $4=$ Always, $3=$ Most of the time, 2=Sometimes, $1=$ Rarely and $0=$ Never. A respondent was considered to exhibit good hand hygiene practices if he/she always washed hands before eating and after visiting the latrine or toilet. To establish the oral health status of $A B Y M$, respondents were asked to use a Likert scale to rate the status of their oral health. In order to establish oral health status, the respondents were asked to rate the state of their teeth, and gums on a scale of $0-5(0=$ Very poor, $1=$ Poor, $2=A v e r a g e, 3=$ Good, $4=$ Very good and $5=$ Excellent. A respondent was considered to have "poor self-rated oral health status" if he rated his gums and or teeth as poor or very poor, and "good self-rated oral health" if he rated his teeth and or gums as average, good, very good or excellent. This approach has previously been used other scholars to measure oral health status (Htun and Peltzer, 2019, Jayasvasti et al., 2019).

\section{Independent variables}

The independent variables included age, residence during school and level of education. To categorise the participant level of education, individuals were asked which class they were attending before the COVID-19 restrictions. ABYM who were in primary five and below were classified as being in "lower primary", ABYM who were in primary six and seven were classified as being in "upper primary", individuals in senior one to senior four were classified as "lower secondary", individuals in senior five and six were classified as "upper secondary" while those at the university and other tertiary institutions of learning were classified as "tertiary". Data on age was collected as a continuous variable and later categorised as 10-13 years, 14-17 years and 18-24 years. Residence was classified as "School" if the respondent slept at school (boarding section), "home" if the respondent slept home during school time (day scholar) and "hostel/hall" if the respondent slept in a hall of residence or hostel during school time.

\section{Data management and analysis}

Data were collected electronically using the KoboCollect mobile application which was installed on android-enabled phones and tablets. We opted for mobile data collection tools to mitigate the risk of transmission of COVID-19 through paper-based questionnairesand to facilitate real-time data capture and entry to minimize errors (Ssekamatte et al., 2020). Research assistants uploaded all the data entry forms daily. Upon submission of the data entry forms, the study coordinator and quantitative data manager cross-checked the data for consistency and errors. After completion of data collection, data were downloaded into 
Excel and cleaned before exporting to STATA version 14.0 for statistical analysis. The descriptive statistics included the measures of central tendency, and measures of dispersion such as the interquartile range. The modified Poisson regression model was used to establish the factors associated with hand hygiene practice among school-going ABYM. A modified Poisson regression is a generalized linear model form of regression analysis used to model count data and contingency tables, and is used when the prevalence of the outcome of interest is greater than $10 \%$ to avoid over estimation of standard errors when a logistic regression model is used under the same conditions (Chen et al., 2018, Zou, 2004, Petersen and Deddens, 2008). Using Odds ratios would overestimate the strength of association between the predictor and outcome variables. A modified Poisson regression model has previously been used to establish the determinants of hand hygiene practices among mothers seeking delivery services from healthcare facilities in the Kampala metropolitan area, Uganda (Kayiwa et al., 2020b).

\section{Results}

\section{Socio-demographic characteristics of the respondents}

A total of 1869 ABYM were interviewed. The mean age of the respondents was 16.1 (standard deviation=3.3 years) while the median age was 17.0 years (IQR=14, 19 years). Nearly half, 46.5\% (870/1869) were aged 18-24 years, more than two-thirds, and 69.7\% (1303/1869) were day scholars. More than a tenth, $12.0 \%(225 / 1869)$ of the respondents were at a tertiary institution such as a university (Table 1$)$.

Table 1

Socio-demographic characteristics of the respondents

\begin{tabular}{|c|c|c|c|}
\hline Variable & Attribute & Frequency $(n=1869)$ & Percentage (\%) \\
\hline \multirow[t]{5}{*}{ Division of Kampala } & Central Division & 206 & 11.0 \\
\hline & Makindye Division & 273 & 14.6 \\
\hline & Nakawa Division & 619 & 33.1 \\
\hline & Kawempe Division & 429 & 23.0 \\
\hline & Rubaga Division & 342 & 18.3 \\
\hline \multirow[t]{3}{*}{ Age category } & $10-13$ & 338 & 18.1 \\
\hline & $14-17$ & 661 & 35.4 \\
\hline & $18-24$ & 870 & 46.5 \\
\hline \multirow[t]{3}{*}{ Residence during school } & School & 437 & 23.4 \\
\hline & Home & 1303 & 69.7 \\
\hline & Hostel/Hall & 129 & 6.9 \\
\hline \multirow[t]{5}{*}{ Level of education } & Lower primary & 158 & 0.5 \\
\hline & Upper primary & 262 & 8.1 \\
\hline & Lower secondary & 827 & 14 \\
\hline & Upper secondary & 397 & 18.5 \\
\hline & Tertiary & 225 & 25.7 \\
\hline
\end{tabular}

\section{Access to drinking water and sanitation facilities}

Majority, 81.4\% (1522/1869) of the respondents had access to a drinking water source at their school. More than half, 56.9\% (1064/1869) of the respondents carried water from home to drink while at school, and more than a tenth, 15.4\% (149/1869) never drank the water from the school sources. Almost all, $98.9 \%$ $(1849 / 1869)$ of the respondents were in schools that had sex-separated toilets/latrines. Almost all, $95.6 \%(1787 / 1869)$ had safe toilets at school, and $97.0 \%$ (1813/1869) had latrines/toilets that provided for privacy (Table 2). 
Table 2

Access to safe drinking water and sanitation facilities among school-going adolescent boys and young men in Kampala, Uganda

\begin{tabular}{|c|c|c|c|}
\hline Variable & Attribute & Frequency $(\mathrm{N}=1869)$ & Percentage (\%) \\
\hline \multicolumn{4}{|l|}{ Availability and access to safe drinking water } \\
\hline \multirow[t]{2}{*}{ Availability of a source of drinking water at school } & No & 347 & 18.6 \\
\hline & Yes & 1522 & 81.4 \\
\hline \multirow[t]{2}{*}{ Carried water from home to drink while you are at school } & No & 805 & 43.1 \\
\hline & Yes & 1064 & 56.9 \\
\hline \multirow[t]{5}{*}{ Frequency of drinking water at the source at school } & Most of the time & 574 & 30.7 \\
\hline & Never & 288 & 15.4 \\
\hline & Rarely & 316 & 16.9 \\
\hline & Sometimes & 542 & 29.0 \\
\hline & No water source at school & 149 & 8.0 \\
\hline \multicolumn{4}{|l|}{ Access and use of sanitation facilities } \\
\hline \multirow[t]{6}{*}{ Frequency of using toilets at school } & Always & 913 & 48.8 \\
\hline & Most of the time & 416 & 22.3 \\
\hline & Never & 12 & 0.6 \\
\hline & Rarely & 109 & 5.8 \\
\hline & Sometimes & 418 & 22.4 \\
\hline & There are no toilets or latrines at school & 1 & 0.1 \\
\hline \multirow[t]{3}{*}{ School has separate toilets or latrines for boys and girls } & No & 18 & 1.0 \\
\hline & No toilets or latrines at school & 2 & 0.1 \\
\hline & Yes & 1849 & 98.9 \\
\hline \multirow[t]{2}{*}{ Toilets at school are safe } & No & 82 & 4.4 \\
\hline & Yes & 1787 & 95.6 \\
\hline \multirow[t]{3}{*}{ Toilets or latrines are clean } & No & 191 & 10.2 \\
\hline & There are no toilets or latrines at school & 1 & 0.1 \\
\hline & Yes & 1677 & 89.7 \\
\hline \multirow[t]{2}{*}{ School toilets/latrines are accessible } & No & 55 & 2.9 \\
\hline & Yes & 1814 & 97.1 \\
\hline \multirow[t]{2}{*}{ School toilets/latrines provide for privacy } & No & 56 & 3.0 \\
\hline & Yes & 1813 & 97.0 \\
\hline
\end{tabular}

\section{Hand hygiene practices among school-going adolescent boys and young men}

More than half, $57.5 \%(1,075 / 1,869)$ exhibited poor hand hygiene practices. Less than a half, $47.7 \%(892 / 1,869)$ of the respondents always washed hands before eating while at school, $62.5 \%(1,169 / 1,869)$ always washed hands after using a toilet, and nearly a tenth, 9.3\% $(174 / 1,869)$ rarely used soap for handwashing while at school. Almost all, $98.3 \%(1837 / 1,869)$ of the respondents had hand hygiene facilities at their toilets at school. However, nearly a tenth, $7.7 \%(143 / 1,869)$ did not have a hand hygiene facility to use before eating food. About $64.8 \%(1211 / 1,869)$ of the respondents were taught in one of the classes during the school year how to avoid infection with worms, and 61.7\% (1154/1,869) were taught where to get treatment for worms (de-worming) (Table 3). 


\begin{tabular}{|c|c|c|c|}
\hline Variable & Attribute & $\begin{array}{l}\text { Frequency } \\
(\mathrm{N}=1869)\end{array}$ & $\begin{array}{l}\text { Percentage } \\
(\%)\end{array}$ \\
\hline \multirow[t]{2}{*}{ Hand hygiene practice } & Poor & 1,075 & 57.5 \\
\hline & Good & 794 & 42.5 \\
\hline \multirow[t]{5}{*}{ Frequency of hand washing before eating while at school } & Always & 892 & 47.7 \\
\hline & Most of the time & 391 & 20.9 \\
\hline & Never & 122 & 6.5 \\
\hline & Rarely & 141 & 7.5 \\
\hline & Sometimes & 323 & 17.3 \\
\hline \multirow[t]{5}{*}{ Mode of hand washing before eating food at home } & $\begin{array}{l}\text { I did not wash my hands before eating during } \\
\text { the past } 30 \text { days }\end{array}$ & 92 & 4.9 \\
\hline & In a dish of water used by others & 179 & 9.6 \\
\hline & In a dish of water used only by me & 279 & 14.9 \\
\hline & Some other way & 238 & 12.7 \\
\hline & Under running water & 1,081 & 57.8 \\
\hline \multirow[t]{5}{*}{ Mode of hand washing before eating food at school } & $\begin{array}{l}\text { I did not wash my hands before eating during } \\
\text { the past } 30 \text { days }\end{array}$ & 142 & 7.6 \\
\hline & In a dish of water used by others & 15 & 0.8 \\
\hline & In a dish of water used only by me & 29 & 1.6 \\
\hline & Some other way & 53 & 2.8 \\
\hline & Under running water & 1,630 & 87.2 \\
\hline \multirow[t]{5}{*}{ Frequency of washing hands after using the toilet } & Always & 1,169 & 62.5 \\
\hline & Most of the time & 454 & 24.3 \\
\hline & Never & 6 & 0.3 \\
\hline & Rarely & 30 & 1.6 \\
\hline & Sometimes & 210 & 11.2 \\
\hline \multirow[t]{6}{*}{ Frequency of using soap for handwashing while at school } & Always & 744 & 39.8 \\
\hline & I did not wash my hands at school & 4 & 0.2 \\
\hline & Most of the time & 359 & 19.2 \\
\hline & Never & 134 & 7.2 \\
\hline & Rarely & 174 & 9.3 \\
\hline & Sometimes & 454 & 24.3 \\
\hline \multirow{2}{*}{$\begin{array}{l}\text { School has a hand hygiene facility at both the eating place and the } \\
\text { toilet/ latrine }\end{array}$} & Yes & 161 & 8.6 \\
\hline & No & 1,708 & 91.4 \\
\hline \multirow[t]{3}{*}{ School has a hand hygiene facility at the toilet or latrine } & No & 31 & 1.7 \\
\hline & There are no toilets or latrines at school & 1 & 0.1 \\
\hline & Yes & 1,837 & 98.3 \\
\hline \multirow[t]{2}{*}{ School has a hand hygiene facility at the eating place } & Yes & 1,726 & 92.3 \\
\hline & No & 143 & 7.7 \\
\hline \multirow{3}{*}{$\begin{array}{l}\text { Was taught in one of the classes the importance of handwashing during } \\
\text { the most recent school year }\end{array}$} & I do not know & 2 & 0.1 \\
\hline & No & 313 & 16.7 \\
\hline & Yes & 1,554 & 83.1 \\
\hline
\end{tabular}

Factors associated with hand hygiene practice 
The prevalence of good hand hygiene practice was 37\% lower among respondents aged 18-24 years compared to those aged 10-13 years (adjusted Prevalence Ratio $[\mathrm{Apr}]=0.63 ; 95 \%$ Confidence Interval $[95 \% \mathrm{Cl}]$ : 0.50, 0.78). The prevalence of good hand hygiene practice was $167 \%$ higher among respondents whose schools had handwashing facilities at both the eating place and the sanitary facilities compared to those whose schools didn't (Apr=2.67; 95\% Cl: 1.84, 3.85) (Table 4).

Table 4

Factors associated with hand hygiene practice among school-going adolescent boys and young men in Kampala, Uganda

\begin{tabular}{|c|c|c|c|c|c|c|}
\hline \multirow[t]{3}{*}{ Variable } & \multirow[t]{3}{*}{ Attribute } & \multirow[t]{3}{*}{$\begin{array}{l}\text { Frequency } \\
(\mathrm{N}=1,869)\end{array}$} & \multicolumn{2}{|c|}{$\begin{array}{l}\text { Hand hygiene } \\
\text { practice }\end{array}$} & \multirow[t]{3}{*}{$\begin{array}{l}\text { Crude prevalence } \\
\text { rations }(95 \% \mathrm{Cl})\end{array}$} & \multirow[t]{3}{*}{$\begin{array}{l}\text { Adjusted prevalence } \\
\text { ratios }(95 \% \mathrm{Cl})\end{array}$} \\
\hline & & & Poor & Good & & \\
\hline & & & n (\%) & n (\%) & & \\
\hline \multirow[t]{3}{*}{ Age category } & $10-13$ & 338 & $\begin{array}{l}159 \\
(47.0)\end{array}$ & $\begin{array}{l}179 \\
(53.0)\end{array}$ & 1.0 & 1.0 \\
\hline & $14-17$ & 661 & $\begin{array}{l}356 \\
(53.9)\end{array}$ & $\begin{array}{l}305 \\
(46.1)\end{array}$ & $0.87(0.76,0.99)$ & $0.88(0.74,1.04)$ \\
\hline & $18-24$ & 870 & $\begin{array}{l}560 \\
(64.4)\end{array}$ & $\begin{array}{l}310 \\
(35.6)\end{array}$ & $0.67(0.58,0.76)$ & $0.63(0.50,0.78)^{\star \star}$ \\
\hline \multirow[t]{5}{*}{ Level of education } & $\begin{array}{l}\text { Lower } \\
\text { primary }\end{array}$ & 158 & $\begin{array}{l}83 \\
(52.5)\end{array}$ & $\begin{array}{l}75 \\
(47.5)\end{array}$ & 1.0 & 1.0 \\
\hline & $\begin{array}{l}\text { Upper } \\
\text { primary }\end{array}$ & 262 & $\begin{array}{l}124 \\
(47.3)\end{array}$ & $\begin{array}{l}138 \\
(52.7)\end{array}$ & $1.10(0.90,1.35)$ & $1.10(0.90,1.34)$ \\
\hline & $\begin{array}{l}\text { Lower } \\
\text { secondary }\end{array}$ & 827 & $\begin{array}{l}488 \\
(59.0)\end{array}$ & $\begin{array}{l}339 \\
(41.0)\end{array}$ & $0.86(0.71,1.03)$ & $1.03(0.82,1.29)$ \\
\hline & $\begin{array}{l}\text { Upper } \\
\text { secondary }\end{array}$ & 397 & $\begin{array}{l}232 \\
(58.4)\end{array}$ & $\begin{array}{l}165 \\
(41.6)\end{array}$ & $0.87(0.71,1.07)$ & $1.29(0.98,1.70)$ \\
\hline & $\begin{array}{l}\text { Tertiary / } \\
\text { University }\end{array}$ & 225 & $\begin{array}{l}148 \\
(65.8)\end{array}$ & $\begin{array}{l}77 \\
(34.2)\end{array}$ & $0.72(0.56,0.92)$ & $1.31(0.91,1.88)$ \\
\hline \multirow[t]{3}{*}{ Residence } & Boarding & 437 & $\begin{array}{l}242 \\
(55.4)\end{array}$ & $\begin{array}{l}195 \\
(44.6)\end{array}$ & 1.0 & 1.0 \\
\hline & Day & 1,303 & $\begin{array}{l}746 \\
(57.3)\end{array}$ & $\begin{array}{l}557 \\
(42.7)\end{array}$ & $0.95(0.84,1.08)$ & $0.96(0.85,1.09)$ \\
\hline & Hostel/Hall & 129 & $\begin{array}{l}87 \\
(67.4)\end{array}$ & $\begin{array}{l}42 \\
(32.6)\end{array}$ & $0.72(0.55,0.95)$ & $0.87(0.60,1.24)$ \\
\hline \multirow[t]{2}{*}{$\begin{array}{l}\text { School has a hand washing station at both the } \\
\text { eating place or toilet facility }\end{array}$} & No & 161 & $\begin{array}{l}136 \\
(84.5)\end{array}$ & $\begin{array}{l}25 \\
(15.5)\end{array}$ & 1.0 & 1.0 \\
\hline & Yes & 1,708 & $\begin{array}{l}939 \\
(55.5)\end{array}$ & $\begin{array}{l}769 \\
(45.0)\end{array}$ & $2.89(2.01,4.17)$ & $2.67(1.84,3.85)^{\star *}$ \\
\hline \multirow[t]{2}{*}{$\begin{array}{l}\text { Classes included lessons on how to avoid } \\
\text { infection with worms }\end{array}$} & No & 658 & $\begin{array}{l}405 \\
(61.6)\end{array}$ & $\begin{array}{l}253 \\
(38.4)\end{array}$ & 1.0 & 1.0 \\
\hline & Yes & 1,211 & $\begin{array}{l}670 \\
(55.3)\end{array}$ & $\begin{array}{l}541 \\
(44.7)\end{array}$ & $1.16(1.03,1.30)$ & $0.94(0.77,1.15)$ \\
\hline \multirow[t]{2}{*}{$\begin{array}{l}\text { Classes included lessons on where to get } \\
\text { treatment for worms (de-worming) }\end{array}$} & No & 715 & $\begin{array}{l}445 \\
(62.2)\end{array}$ & $\begin{array}{l}270 \\
(37.8)\end{array}$ & 1.0 & 1.0 \\
\hline & Yes & 1,154 & $\begin{array}{l}630 \\
(54.6)\end{array}$ & $\begin{array}{l}524 \\
(45.4)\end{array}$ & $1.20(1.07,1.34)$ & $1.15(0.94,1.40)$ \\
\hline
\end{tabular}

\section{Oral health of school-going adolescent boys and young men}

About $3.4 \%$ (61/1869) rated their oral health status as poor. Over $26.4 \%(495 / 1869)$ of the respondents reported having at least one cavity in their teeth, $18.7 \%$ (349/1869) had difficulty biting hard foods, $13.3 \%$ (248/1869) had difficulty chewing, $6.0 \%(113 / 1869)$ avoided smiling or laughing because of appearance of teeth and $16.1 \%(301 / 1869)$ missed school in the last 12 months due to a toothache. The frequency of missing school among the 301 respondents was $52.8 \%$ (159/301) for sometimes, $1 \%$ (3/301) for always, 10\% (30/301) for most of the time, $4.7 \%(14 / 301)$ for never and $31.6 \%$ (95/301) for rarely. About $20.9 \%$ (391/1869) of the respondents had visited a dentist at least once in the last 12 months. Out of the 391 respondents who visited the dentist, $12.0 \%$ (47/391) did so for a check-up or dental examination, 11.8\% (46/391) for follow-up treatment from an earlier visit and 76.2\% (298/391) because something was wrong with their teeth or gums (Table 5). 
Table 5

Oral Health Status of adolescent boys and young men in Kampala, Uganda

\begin{tabular}{|c|c|c|c|}
\hline Variable & Attribute & $\begin{array}{l}\text { Frequency } \\
(\mathrm{N}=1,869)\end{array}$ & $\begin{array}{l}\text { Percentage } \\
(\%)\end{array}$ \\
\hline \multirow[t]{2}{*}{ Self-rated oral health status } & Good & 1,805 & 96.6 \\
\hline & Poor & 64 & 3.4 \\
\hline \multirow[t]{6}{*}{ Respondent description of their oral health } & Excellent & 523 & 28.0 \\
\hline & Very good & 471 & 25.2 \\
\hline & Good & 589 & 31.5 \\
\hline & Average & 230 & 12.3 \\
\hline & Poor & 53 & 2.8 \\
\hline & Very poor & 3 & 0.2 \\
\hline \multirow[t]{6}{*}{ Respondent description of their gum health } & Excellent & 596 & 31.9 \\
\hline & Very good & 502 & 26.9 \\
\hline & Good & 553 & 29.6 \\
\hline & Average & 182 & 9.7 \\
\hline & Poor & 33 & 1.8 \\
\hline & Very poor & 3 & 0.2 \\
\hline \multirow[t]{2}{*}{ Tooth ache led to missing school during the last 12 months } & No & 1,568 & 83.9 \\
\hline & Yes & 301 & 16.1 \\
\hline \multirow[t]{3}{*}{ Uses tooth paste containing fluoride } & I do not know & 115 & 6.2 \\
\hline & No & 71 & 3.8 \\
\hline & Yes & 1,683 & 90.0 \\
\hline \multirow[t]{5}{*}{ Last time you saw a dentist for a checkup, exam, teeth cleaning or other dental work } & $\begin{array}{l}\text { Between } 12 \text { and } 24 \\
\text { months ago }\end{array}$ & 121 & 6.5 \\
\hline & $\begin{array}{l}\text { During the past } 12 \\
\text { months }\end{array}$ & 336 & 18.0 \\
\hline & I do not know & 22 & 1.2 \\
\hline & $\begin{array}{l}\text { More than } 24 \text { months } \\
\text { ago }\end{array}$ & 326 & 17.4 \\
\hline & Never & 1,064 & 56.9 \\
\hline \multirow[t]{6}{*}{ Number of times respondent visited the dentist in the last 12 months } & 0 times & 1,478 & 79.1 \\
\hline & 1 time & 223 & 11.9 \\
\hline & 2 times & 99 & 5.3 \\
\hline & 3 times & 30 & 1.6 \\
\hline & 4 times & 22 & 1.2 \\
\hline & 5 or more times & 17 & 0.9 \\
\hline \multirow[t]{6}{*}{ Medium most often used to clean teeth or gums } & Charcoal & 6 & 0.3 \\
\hline & Dental floss or thread & 2 & 0.1 \\
\hline & Plastic toothpicks & 2 & 0.1 \\
\hline & Something else & 2 & 0.1 \\
\hline & Toothbrush & 1,853 & 99.1 \\
\hline & Wooden toothpicks & 4 & 0.2 \\
\hline \multirow[t]{2}{*}{ Had difficulty biting hard foods } & No & 1,520 & 81.3 \\
\hline & Yes & 349 & 18.7 \\
\hline Satisfied with the appearance of your teeth & No & 319 & 17.1 \\
\hline
\end{tabular}




\begin{tabular}{|c|c|c|c|}
\hline Variable & Attribute & $\begin{array}{l}\text { Frequency } \\
(\mathrm{N}=1,869)\end{array}$ & $\begin{array}{l}\text { Percentage } \\
(\%)\end{array}$ \\
\hline & Yes & 1,550 & 82.9 \\
\hline \multirow[t]{2}{*}{ Had difficulty chewing } & No & 1,621 & 86.7 \\
\hline & Yes & 248 & 13.3 \\
\hline \multirow[t]{2}{*}{ Avoided smiling or laughing because of appearance of teeth } & No & 1,756 & 94.0 \\
\hline & Yes & 113 & 6.0 \\
\hline \multirow[t]{2}{*}{ Students make fun of your teeth } & No & 1,796 & 96.1 \\
\hline & Yes & 73 & 3.9 \\
\hline \multirow[t]{6}{*}{ Number of cavities in your permanent teeth } & 0 cavities & 1,364 & 73.0 \\
\hline & 1 cavity & 298 & 15.9 \\
\hline & 2 or 3 cavities & 161 & 8.6 \\
\hline & 4 or 5 cavities & 30 & 1.6 \\
\hline & 6 or more cavities & 6 & 0.3 \\
\hline & I do not know & 10 & 0.5 \\
\hline \multirow{3}{*}{$\begin{array}{l}\text { Was taught in one of the classes the importance of cleaning or brushing your teeth during } \\
\text { the most recent school year }\end{array}$} & I do not know & 4 & 0.2 \\
\hline & No & 338 & 18.1 \\
\hline & Yes & 1,527 & 81.7 \\
\hline
\end{tabular}

\section{Discussion}

The main objective of the study was to establish water, sanitation and hygiene behaviours and the oral health status of school-going adolescent boys and young men in Kampala, Uganda. Our study revealed that majority of the respondents had access to safe drinking water and sanitation facilities at school. However, hand hygiene was suboptimal since less than two-thirds always washed hands after using the toilet or latrine, and less than half always practiced hand hygiene before eating while at school. Regarding the status of oral health of ABYM, $26.4 \%$ had at least one cavity in their teeth, and more than a tenth had missed school in the last 12 months due to a toothache.

The current study revealed that majority of ABYM in Kampala had access to safe drinking water while at school. This is not surprising given that the ABYM in our study were studying from schools in the capital city of Kampala which has a relatively high access compared other settings in Uganda. Water supply in Kampala is managed by the National Water and Sewerage Corporation (NWSC), a public utility company with over 1,395,649 operations at an access rate of $81 \%$ in the area (MWE, 2021). Although we did not collect data on water sources used by ABYM at school, most institutions including schools are connected to a piped water network managed by NWSC, of which the water is chlorinated and considered safe for human consumption (Kayiwa et al., 2020a). Nonetheless, our study revealed that more than half of the ABYM in Kampala carried water from home to drink while at school. This finding indicates that, whereas drinking water was available at the schools attended by ABYM, access was limited. It is likely that students including ABYM are restricted from accessing water especially when they are attending classes which prompts them to carry their own from home to drink at school. Available evidence also indicates that students, teachers and some members of the public believe that some water sources in schools could be unsafe (Long et al., 2018, Kenney et al., 2020). This may have prompted some ABYM to carry water from home to drink while at school. These findings suggest the need for school authorities to reassure students about the safety and quality of drinking water at school, and to provide appropriate water vessels to enable the students to drink water.

Majority of the respondents had access to safe, clean, private and sex-disaggregated sanitation facilities (latrines or toilets) at their schools. This finding indicates an important stride to achieving universal access to sanitation among students in educational settings in Kampala. Availability of safe, private and sex-disaggregated sanitation facilities is a prerequisite for the establishment of educational settings which is why almost all schools had them. The high proportion of schools with clean sanitation facilities indicates attention toward improving the safety of the students, and can immensely contribute to the reduction in WASH-related diseases such as cholera, typhoid and dysentery (Kimbugwe et al., 2018, Abney et al., 2021). Disaggregation based on sex increases the utilisation of sanitary facilities by ensuring adequate privacy and promotes the safety and dignity of users (Kowaleski, 2020, Ncube et al., 2020).

Less than half of ABYM in Kampala exhibited good hand hygiene practices defined as always washing hands before eating and using a toilet or latrine. This finding should worry school and health authorities given the impact of poor hand hygiene practices on the transmission of WASH-related diseases, and COVID-19. The low proportion of respondents who exhibited good hand hygiene practices may have resulted from inadequate awareness of the impact of hygiene on the transmission of infectious disease agents and a negative attitude toward hand hygiene among ABYM. Although the school curricula incorporate aspects of WASH, it is likely that it is not accorded adequate time to influence behavioural change. The limited access to hand hygiene facilities at strategic points such as the eating places and sanitary facilities may also have limited good hand hygiene practices among ABYM. The high proportion of private and public schools that do not provide soap and water for handwashing near toilets and pit latrines in Kampala (Nvule and Kiconco, 2021), could also explain the low proportion of ABYM with good hand hygiene practices reported in this study. Our finding concurs with earlier studies which revealed low 
utilisation of hand hygiene facilities and consequently poor hand hygiene practice among students in Mbale City, Uganda (Katamba and Nambale) and adolescents in low-and middle income countries (Smith et al., 2020).

The lower proportion of good hand hygiene practice among ABYM aged 18-24 years compared to those aged 10-14 years could be due to limited access to water and hand hygiene facilities in their educational settings. Majority of individuals aged 18-24 years are likely to be enrolled in tertiary institutions (UBOS, 2016), where access to water and hand hygiene facilities is a challenge. Our finding is consistent with an earlier study which indicated high rates of appropriate hand hygiene practice among young adolecents compared to the older ones (Jatrana et al., 2021a).It is also worth noting that ABYM in studying in schools with hand washing facilities at both the eating place or toilet facility were more likely to exhibit good hygiene practices compared to their counterparts who didn't. This is because availability of hand hygiene facilities in places where hand hygiene must be practiced increases the opportunity of practicing it. Earlier studies revealed that having hand hygiene facilities with water and soap at critical points increases their utilisation, and consequently hand hygiene practice (Namara et al., 2020).

Nearly a tenth of ABYM washed their hands in a dish of water used by others while at home compared to less than $1 \%$ while at school. Besides, a higher proportion of ABYM washed their hand under running water at school (87.2\%) compared to home (57.8\%). Hand washing is more effective when done under running water. Communal handwashing facilities such as dishes or bowls shared by others increase the risk of transmission of pathogens such as Salmonella species, Citrobacter species and Escherichia coli (Enoch and Pius, 2018, Tetteh-Quarcoo et al., 2016). A study aimed to determine the microbial content of bowl water used for communal handwashing in preschools in Ghana revealed a high prevalence of Staphylococcus and E. coli species, before and after children had washed their hands (Tetteh-Quarcoo et al., 2016). The high proportion of children who washed hands under running water at school compared to home may be attributed to more access to water while at school compared to home. Schools in Kampala are also more likely to invest in water supply due to higher incomes compared to the homes of ABYM. Thus, schools are more likely to have water storage facilities such as tanks with taps compared to homes, which facilitates hand washing under running water.

Besides the high prevalence of poor hand hygiene practice, more than a tenth of ABYM described their oral health status as poor, with $17.1 \%$ not satisfied with the appearance of their teeth. The poor oral health status was also evidenced by the high prevalence of cavities, and the proportion of ABYM who found it difficult biting and chewing. The poor health status of ABYM may be attributed to poor oral health and lack of awareness of oral hygiene among ABYM in Kampala. Besides, sweet foods and beverages which are known to increase the risk of tooth decay (Hardy et al., 2018), are a delicacy for ABYM in Kampala and worldwide. The high affinity for sweet foods such as cakes and sweets could explain the high prevalence of cavities/tooth decay among ABYM in Kampala. Studies elsewhere have also linked the high prevalence of cavities/tooth decay among adolescents and young adults to sweet foods and beverages (Tudoroniu et al., 2020, Broomhead et al., 2021). The poor oral health status reported in the current study contributed to absenteeism and avoidance to smile or laugh, which all have negative consequences on education aspirations and the health and wellbeing of ABYM. Just like this study, earlier studies among adolescents have also reported the impact of poor oral health on school attendance and performance, mental health and quality of life (Jessani et al., 2021, Rebelo et al., 2019, Ruff et al., 2019, Karki et al., 2019, Maharani et al., 2017, Lambert et al., 2017, Santos et al., 2017). The current study, therefore, suggests the need for the school and health authorities to create awareness of oral health and its impact on school attendance and the quality of life of adolescents and young adults, especially boys and men.

\section{Strengths and limitations}

This is probably the first study to establish WASH behaviours and the oral health status of school-going ABYM in an urban setting. The study was conducted in Kampala which is representative of cities in the global south (Ssekamatte et al., 2019) and used a large sample size which makes the findings and conclusions more generalisable. Nonetheless, our study had a few limitations which future studies need to address. During the assessment of hand hygiene practice, we used self-reports, which are subject to social desirability bias and overestimation of handwashing behaviour (Ram, 2019).

\section{Conclusion}

This study reveals that the majority of ABYM have access to drinking water and private, safe and sex-separated sanitary facilities while at school. Despite the availability of safe drinking water at school, more than half of ABYM still carried water from home to drink while at school, which indicates structural limitations to access when in need. The current study also brings to light the high prevalence of poor hand hygiene practice evidenced by a low proportion of ABYM that always wash hands before eating and after visiting a toilet. Availability of hand hygiene facilities at both the eating place was positively associated with good hand hygiene practices while being aged 18-24 years was negatively associated with good hand hygiene practices. In addition to the low prevalence of good hand hygiene practice, our study unearthed a high prevalence of poor oral health status evidenced by a high proportion of $A B Y M$ with tooth decay/cavities and difficulties in biting and chewing. Due to poor oral health status, some ABYM missed school and avoided smiling or laughing, which may have affected their mental health and wellbeing. The current study suggests the need to strengthen health education especially regarding hygiene and oral health. Education and health authorities also have the task of extending dental services to schools and institutions of higher learning given the high prevalence of tooth decay in these settings.

\section{Abbreviations}

ABYM: Adolescent Boys and Young Men

MoES: Ministry of Education and Sports

SDG: Sustainable Development Goals 
UN: United Nations

UNICEF: United Nations Children's Fund

WASH: Water, Sanitation and Hygiene

WHO: World Health Organisation

\section{Declarations}

\section{Ethics approval and consent to participate}

Ethical approval was obtained from the Makerere University School of Public Health Higher Degrees Research and Ethics Committee (protocol number 757) and the study was registered with the Uganda National Council for Science and Technology (registration number SS5240). Administrative clearance was sought from the Ministry of Education and Sports and Kampala Capital City Authority. All methods were performed in accordance with the relevant guidelines and regulations (Declaration of Helsinki). During the interviews, we obtained informed consent from all respondents aged above 18 years of age. Informed consent was obtained from all parents of participants aged 10-17 years. In addition, participants aged 10-17 years were asked to provide their assent prior to being interviewed. Access to the collected data was restricted to only the study team.

\section{Consent to publish}

Not applicable

\section{Availability of data and materials}

All data generated or analysed during this study are included in this published article and its supplementary information files.

\section{Competing interests}

The authors declare that they have no competing interests.

\section{Funding}

This study was funded by the government of Uganda through the Makerere University Research and Innovations Fund (RIF). The funding body did not play a role in the design of the study and collection, analysis, and interpretation of data, and writing of the manuscript.

\section{Authors' contributions}

TS, JKBM, SKN, JMS and RKW conceptualised the study, participated in data collection, analysis and drafting the manuscript. All authors read and approved this manuscript before submission to this journal.

\section{Acknowledgement}

We would like to thank the study participants for sparing their time to participate in the study. Our sincere gratitude also goes to the parents of the minors who consented for their participation. We remain indebted to our study guides (mobilisers) and the local area authorities for their cooperation and support during data collection. Special thanks also go to team leaders and research assistants for their invaluable effort during data collection.

\section{References}

1. ABBASS, M. M. S., MAHMOUD, S. A., EL MOSHY, S., RADY, D., ABUBAKR, N., RADWAN, I. A., AHMED, A., ABDOU, A. \& AL JAWALDEH, A. 2019. The prevalence of dental caries among Egyptian children and adolescences and its association with age, socioeconomic status, dietary habits and other risk factors. A cross-sectional study. F1000Research, 8, 8-8.

2. ABNEY, S. E., BRIGHT, K. R., MCKINNEY, J., IJAZ, M. K. \& GERBA, C. P. 2021. Toilet hygiene-review and research needs. Journal of Applied Microbiology, n/a.

3. AHMED, J., WONG, L. P., CHUA, Y. P., HYDRIE, M. Z. I. \& CHANNA, N. 2021. Drinking water, sanitation, and hygiene (WASH) situation in primary schools of Pakistan: the impact of WASH-related interventions and policy on children school performance. Environmental Science and Pollution Research.

4. AMIN, A., KÅGESTEN, A., ADEBAYO, E. \& CHANDRA-MOULI, V. 2018. Addressing gender socialization and masculinity norms among adolescent boys: policy and programmatic implications. Journal of Adolescent Health, 62, S3-S5.

5. AZHAR, S., FAISAL, M. \& AMAN, A. 2021. Self-reported maternal handwashing knowledge and behaviours observed in a rural hospital in Pakistan. Eastern Mediterranean Health Journal, 27.

6. BAIJU, R. M. P., PETER, E., NAYAR, B. R., VARUGHESE, J. M. \& VARGHESE, N. O. 2019. Prevalence and predictors of early periodontal disease among adolescents. Journal of Indian Society of Periodontology, 23, 356.

7. BARTRAM, J., SIMS, J. \& CHARTIER, Y. 2009. Water, sanitation and hygiene standards for schools in low-cost settings, World Health Organization.

8. BATWALA, V., MULOGO, E. M. \& ARUBAKU, W. 2007. Oral health status of school children in Mbarara, Uganda. Afr Health Sci, 7, $233-8$.

9. BELL, D. L., BRELAND, D. J. \& OTT, M. A. 2013. Adolescent and young adult male health: a review. Pediatrics, 132, 535-546.

Page $12 / 16$ 
10. BENZIAN, H., GUARNIZO-HERREÑO, C. C., KEARNS, C., MURIITHI, M. W. \& WATT, R. G. 2021. The WHO global strategy for oral health: an opportunity for bold action. The Lancet, 398, 192-194.

11. BERNABE, E., MARCENES, W., HERNANDEZ, C., BAILEY, J., ABREU, L., ALIPOUR, V., AMINI, S., ARABLOO, J. \& AREFI, Z. 2020. Global, regional, and national levels and trends in burden of oral conditions from 1990 to 2017: a systematic analysis for the global burden of disease 2017 study. Journal of dental research, 99, 362-373.

12. BROOMHEAD, T., BALLAS, D. \& BAKER, S. 2021. Neighbourhoods and oral health: Agent-based modelling of tooth decay. Health \& place, $71,102657$.

13. CAVILL, S., MOTT, J., TYNDALE-BISCOE, P., BOND, M., HUGGETT, C. \& WAMERA, E. 2018. Engaging men and boys in sanitation and hygiene programmes.

14. CHAMBERS, R. \& MYERS, J. 2016. Norms, Knowledge, and Usage, Frontiers of CLTS: Innovations and Insights, Issue 7. Brighton: IDS.

15. CHEN, W., QIAN, L., SHI, J. \& FRANKLIN, M. 2018. Comparing performance between log-binomial and robust Poisson regression models for estimating risk ratios under model misspecification. BMC Medical Research Methodology, 18, 63.

16. COFFEY, D., GUPTA, A., HATHI, P., KHURANA, N., SRIVASTAV, N., VYAS, S. \& SPEARS, D. 2014. Open defecation: evidence from a new survey in rural north India. Economic and Political Weekly, 43-55.

17. DUIJSTER, D., BUXTON, H., BENZIAN, H., DIMAISIP-NABUAB, J., MONSE, B., VOLGENANT, C. \& DREIBELBIS, R. 2020. Impact of a school-based water, sanitation and hygiene programme on children's independent handwashing and toothbrushing habits: a cluster-randomised trial. International journal of public health, 65, 1699-1709.

18. ENOCH, A. S. \& PIUS, M. T. 2018. BACTERIA ASSOCIATED WITH HAND-WASHING BOWLS AND WATER IN PUBLIC RESTAURANTS.

19. GOVERNMENT OF UGANDA. 2020. VOLUNTARY NATIONAL REVIEW REPORT ON THE IMPLEMENTATION OF THE 2030 AGENDA FOR SUSTAINABLE DEVELOPMENT [Online]. Kampala: Office of the Prime minister, Government of Uganda. Available: https://sustainabledevelopment.un.org/content/documents/26354VNR_2020_Uganda_Report.pdf [Accessed 02-October 2021].

20. HAN, L., GAO, X., LIAO, M., YU, X., ZHANG, R., LIU, S. \& ZENG, F. 2020. Hygiene practices among young adolescents aged 12-15 years in low- and middleincome countries: a population-based study. Journal of global health, 10, 020436-020436.

21. HARDY, L. L., BELL, J., BAUMAN, A. \& MIHRSHAHI, S. 2018. Association between adolescents' consumption of total and different types of sugarsweetened beverages with oral health impacts and weight status. Australian and New Zealand journal of public health, 42, $22-26$.

22. HENNEGAN, J., ZIMMERMAN, L., SHANNON, A. K., EXUM, N. G., OLAOLORUN, F., OMOLUABI, E. \& SCHWAB, K. J. 2018. The Relationship between Household Sanitation and Women's Experience of Menstrual Hygiene: Findings from a Cross-Sectional Survey in Kaduna State, Nigeria. International Journal of Environmental Research and Public Health, 15, 905.

23. HTUN, K. C. S. S. \& PELTZER, K. 2019. Oral health-related quality of life among community dwelling middle-aged and older adults in an urban area in Magway region, Myanmar. Nagoya journal of medical science, 81, 103.

24. JATRANA, S., HASAN, M., MAMUN, A. A. \& FATIMA, Y. 2021a. Global Variation in Hand Hygiene Practices Among Adolescents: The Role of Family and School-Level Factors. International journal of environmental research and public health, 18, 4984.

25. JATRANA, S., HASAN, M. M., MAMUN, A. A. \& FATIMA, Y. 2021b. Global Variation in Hand Hygiene Practices Among Adolescents: The Role of Family and School-Level Factors. International journal of environmental research and public health, 18, 4984.

26. JAYASVASTI, I., HTUN, K. C. S. S. \& PELTZER, K. 2019. Self-rated oral health status and social and health determinants among 35-65 year-old persons in one region in Myanmar: A cross-sectional study. Clinical, cosmetic and investigational dentistry, 11, 339.

27. JESSANI, A., CHOI, J., EL-RABBANY, A., LEFOKA, P., QUADRI, M. F. A. \& LARONDE, D. M. 2021. Oral Health and Psychosocial Predictors of Quality of Life and General Well-Being among Adolescents in Lesotho, Southern Africa. Children, 8, 582.

28. JOHNSON, R. K., LAMB, M., ANDERSON, H., PIETERS-ARROYO, M., ANDERSON, B. T., BOLAÑOS, G. A. \& ASTURIAS, E. J. 2019. The global school-based student health survey as a tool to guide adolescent health interventions in rural Guatemala. BMC public health, 19, 1-9.

29. KABWAMA, S. N., MATOVU, J. K., SSENKUSU, J. M., SSEKAMATTE, T. \& WANYENZE, R. K. 2021a. Alcohol use and associated factors among adolescent boys and young men in Kampala, Uganda. Substance Abuse Treatment, Prevention, and Policy, 16, 1-9.

30. KABWAMA, S. N., MATOVU, J. K. B., SSENKUSU, J. M., SSEKAMATTE, T. \& WANYENZE, R. K. 2021b. Alcohol use and associated factors among adolescent boys and young men in Kampala, Uganda. Substance Abuse Treatment, Prevention, and Policy, 16, 49.

31. KARKI, S., PÄKKILÄ, J., LAITALA, M. L., HUMAGAIN, M. \& ANTTONEN, V. 2019. Influence of dental caries on oral health-related quality of life, school absenteeism and school performance among Nepalese schoolchildren. Community dentistry and oral epidemiology, 47, 461-469.

32. KATAMBA, P. \& NAMBALE, G. N. Hand Hygiene Knowledge and Utilization of Hand-Washing Facilities among Pupils in Primary Schools in Mbale Municipality, Uganda. Rethinking Sustainable Development Goals in Africa: Emerging Trends and Issues, 55.

33. KATO-WALLACE, J., BARKER, G., SHARAFI, L., MORA, L. \& LAURO, G. 2016. Adolescent boys and young men: engaging them as supporters of gender equality and health and understanding their vulnerabilities. Washington, DC and New York: Promundo and UNFPA.

34. KAYIWA, D., MUGAMBE, R. K., MSELLE, J. S., ISUNJU, J. B., SSEMPEBWA, J. C., WAFULA, S. T., NDEJJO, R., KANSIIME, W. K., NALUGYA, A., WAGABA, B., ZZIWA, J. B., BWIRE, C., BUREGYEYA, E., RADOOLI, M. O., KIMBUGWE, C., NAMANYA, E., BATEGANYA, N. L., MCGRIFF, J. A., WANG, Y., SSEKAMATTE, T. \& YAKUBU, H. 2020a. Assessment of water, sanitation and hygiene service availability in healthcare facilities in the greater Kampala metropolitan area, Uganda. BMC Public Health, 20, 1767.

35. KAYIWA, D., SEMBUCHE MSELLE, J., ISUNJU, J. B., SSEKAMATTE, T., TSEBENI WAFULA, S., MULEME, J., SSEMPEBWA, J., NAMANYA, E., BATEGANYA, N. L. \& YAKUBU, H. 2020b. Determinants of hygiene practices among mothers seeking delivery services from healthcare facilities in the Kampala metropolitan area, Uganda. International journal of environmental health research, 1-13. 
36. KENNEY, E. L., DALY, J. G., LEE, R. M., MOZAFFARIAN, R. S., WALSH, K., CARTER, J. \& GORTMAKER, S. L. 2020. Providing students with adequate school drinking water access in an era of aging infrastructure: A mixed methods investigation. International journal of environmental research and public health, 17,62 .

37. KIMBUGWE, C., MURUNGU, R., WATAKO, D. \& TUMISIIME, F. 2018. Blockages to Service sustainability of Water, Sanitation and Hygiene in Schools Case study of selected public schools in Kampala Uganda. OIDA International Journal of Sustainable Development, 11, 61-72.

38. KOWALESKI, E. 2020. Land of the Clean and the Home of the Segregated: Sex-Separated Bathrooms in the Northeastern United States, $1870-1920$.

39. KWIRINGIRA, J., ATEKYEREZA, P., NIWAGABA, C. \& GÜNTHER, I. 2014. Gender variations in access, choice to use and cleaning of shared latrines; experiences from Kampala Slums, Uganda. BMC public health, 14, 1180-1180.

40. LAMBERT, M. J., VANOBBERGEN, J. S., MARTENS, L. C. \& DE VISSCHERE, L. M. 2017. Socioeconomic inequalities in caries experience, care level and dental attendance in primary school children in Belgium: a cross-sectional survey. BMJ open, 7, e015042.

41. LONG, M. W., GORTMAKER, S. L., PATEL, A. I., ONUFRAK, S. J., WILKING, C. L. \& CRADOCK, A. L. 2018. Public perception of quality and support for required access to drinking water in schools and parks. American Journal of Health Promotion, 32, $72-74$.

42. LOPEZ, V. K., BERROCAL, V. J., ANGULO, B. C., RAM, P. K., TROSTLE, J. \& EISENBERG, J. N. 2019. Determinants of latrine use behavior: the psychosocial proxies of individual-level defecation practices in rural coastal Ecuador. The American journal of tropical medicine and hygiene, $100,733$.

43. MAHARANI, D. A., ADIATMAN, M., RAHARDJO, A., BURNSIDE, G. \& PINE, C. 2017. An assessment of the impacts of child oral health in Indonesia and associations with self-esteem, school performance and perceived employability. BMC Oral Health, 17, 1-10.

44. MASENTO, N. A., GOLIGHTLY, M., FIELD, D. T., BUTLER, L. T. \& VAN REEKUM, C. M. 2014. Effects of hydration status on cognitive performance and mood. British Journal of Nutrition, 111, 1841-1852.

45. MATOVU, J. K., KABWAMA, S. N., SSEKAMATTE, T., SSENKUSU, J. \& WANYENZE, R. K. 2021a. COVID-19 Awareness, Adoption of COVID-19 Preventive Measures, and Effects of COVID-19 Lockdown Among Adolescent Boys and Young Men in Kampala, Uganda. Journal of Community Health, 1-12.

46. MATOVU, J. K. B., KABWAMA, S. N., SSEKAMATTE, T., SSENKUSU, J. \& WANYENZE, R. K. 2021b. COVID-19 Awareness, Adoption of COVID-19 Preventive Measures, and Effects of COVID-19 Lockdown Among Adolescent Boys and Young Men in Kampala, Uganda. Journal of community health, $46,842-853$.

47. MINISTRY OF EDUCATION AND SPORTS. 2017. GUIDELINES FOR THREE STAR APPROACH FOR PLANING AND IMPLEMENTATION OF WASH IN SCHOOLS [Online]. Kampala: MINISTRY OF EDUCATION AND SPORTS. Available:

https://www.mwe.go.ug/sites/default/files/library/GUIDELINES\%20FOR\%203\%20STAR\%20updated.pdf [Accessed 11th October 2021].

48. MINISTRY OF EDUCATION AND SPORTS 2021. MENSTRUAL HEALTH AND HYGIENE MANAGEMENT GUIDELINES FOR SCHOOLS AND EDUCATION INSTITUTIONS IN UGANDA. Kampala.

49. MINISTRY OF HEALTH \& WHO. 2007. NATIONAL ORAL HEALTH POLICY [Online]. Kampala: Ministry of Health. Available: https://www.health.go.ug/cause/national-oral-health-policy/ [Accessed 14th October 2021].

50. MUKHERJEE, S. \& ALAM, M. 2017. WASH 5 Star approach: addressing hygiene behaviour in schools of rural Bangladesh.

51. MWE. 2021. Water Supply Atalas-Uganda [Online]. Kampala: Ministry of Water and Environment Available: http://wsdb.mwe.go.ug/index.php/reports/national [Accessed 08-October 2021 2021].

52. NAMARA, F., OMONA, K. \& MBABAZI, S. 2020. Barriers and motivators to participation in hand washing promotion programs at household level among refugees in Rhino Settlement, Arua District__ Uganda. Cogent Medicine, 7, 1757184.

53. NCUBE, F., KANDA, A., CHAHWANDA, M., MACHERERA, M. \& NGWENYA, B. 2020. Predictors of hand hygiene behaviours among primary and secondary school children in a rural district setting in Zimbabwe: a cross-sectional epidemiologic study. Journal of Water, Sanitation and Hygiene for Development, $10,851-861$.

54. NVULE, H. P. \& KICONCO, A. 2021. Using Action Research to Improve Hand Washing among Staff and Pupils of St. Paul Primary School Nsambya, Makindye Division-Kampala District, Uganda. Student's Journal of Health Research Africa, 2, 19-19.

55. PETERSEN, M. R. \& DEDDENS, J. A. 2008. A comparison of two methods for estimating prevalence ratios. BMC medical research methodology, 8, 1-9.

56. RAM, P. 2019. Practical guidance for measuring handwashing behavior: 2013 Update: Water and Sanitation Program; 2013. Availabe from: https://www. wsp. org/sites/wsp/files/publications/WSP-Practical-Guidance-Measuring-Handwashing-Behavior-2013-Update. pdf. Accessed, 15.

57. REBELO, M. A. B., REBELO VIEIRA, J. M., PEREIRA, J. V., QUADROS, L. N. \& VETTORE, M. V. 2019. Does oral health influence school performance and school attendance? A systematic review and meta-analysis. International journal of paediatric dentistry, 29, 138-148.

58. RUFF, R. R., SENTHI, S., SUSSER, S. R. \& TSUTSUI, A. 2019. Oral health, academic performance, and school absenteeism in children and adolescents: A systematic review and meta-analysis. The Journal of the American Dental Association, 150, 111-121. e4.

59. SANTOS, P. S., CREMONESI, A. L., QUISPE, R. A. \& RUBIRA, C. M. 2017. The impact of oral health on quality of life in individuals with head and neck cancer after radiotherapy: the importance of dentistry in psychosocial issues. Acta Odontol Latinoam, 30, 62-7.

60. SKOLMOWSKA, D., GŁĄBSKA, D. \& GUZEK, D. 2020. Hand hygiene behaviors in a representative sample of Polish adolescents in regions stratified by COVID-19 morbidity and by confounding variables (PLACE-19 Study): Is there any association? Pathogens, 9, 1011.

61. SMITH, L., BUTLER, L., TULLY, M. A., JACOB, L., BARNETT, Y., LÓPEZ-SÁNCHEZ, G. F., LÓPEZ-BUENO, R., SHIN, J. I., MCDERMOTT, D., PFEIFER, B. A., PIZZOL, D. \& KOYANAGI, A. 2020. Hand-Washing Practices among Adolescents Aged 12-15 Years from 80 Countries. International journal of environmental research and public health, 18, 138.

62. SOMMER, M., CARUSO, B. A., SAHIN, M., CALDERON, T., CAVILL, S., MAHON, T. \& PHILLIPS-HOWARD, P. A. 2016. A Time for Global Action: Addressing Girls' Menstrual Hygiene Management Needs in Schools. PLOS Medicine, 13, e1001962. 
63. SOMMER, M., CARUSO, B. A., TORONDEL, B., WARREN, E. C., YAMAKOSHI, B., HAVER, J., LONG, J., MAHON, T., NALINPONGUIT, E., OKWARO, N. \& PHILLIPS-HOWARD, P. A. 2021. Menstrual hygiene management in schools: midway progress update on the "MHM in Ten" 2014-2024 global agenda. Health Research Policy and Systems, 19, 1.

64. SPANEMBERG, J., CARDOSO, J., SLOB, E. \& LÓPEZ-LÓPEZ, J. 2019. Quality of life related to oral health and its impact in adults. Journal of stomatology, oral and maxillofacial surgery, 120, 234-239.

65. SSEKAMATTE, T., ISUNJU, J. B., BALUGABA, B. E., NAKIRYA, D., OSURET, J., MGUNI, P., MUGAMBE, R. \& VAN VLIET, B. 2019. Opportunities and barriers to effective operation and maintenance of public toilets in informal settlements: perspectives from toilet operators in Kampala. International journal of environmental health research, 29, 359-370.

66. SSEKAMATTE, T., MUKAMA, T., KIBIRA, S. P. S., NDEJJO, R., BUKENYA, J. N., KIMOGA, Z. P. A., ETAJAK, S., NUWEMATSIKO, R., BUREGYEYA, E., SSEMPEBWA, J. C., ISUNJU, J. B., MUGAMBE, R. K., NALUGYA, A., WAFULA, S. T. \& MUTYOBA, J. N. 2020. Hepatitis B screening and vaccination status of healthcare providers in Wakiso district, Uganda. PLOS ONE, 15, e0235470.

67. TADDESE, A. A., DAGNEW, B., DAGNE, H. \& ANDUALEM, Z. 2020. Mother's Handwashing Practices and Health Outcomes of Under-Five Children in Northwest Ethiopia. Pediatric health, medicine and therapeutics, 11, 101.

68. TETTEH-QUARCOO, P. B., ANIM-BAIDOO, I., ATTAH, S. K., ABDUL-LATIF BAAKO, B., OPINTAN, J. A., MINAMOR, A. A., ABDUL-RAHMAN, M. \& AYEH-KUMI, P. F. 2016. Microbial Content of "Bowl Water" Used for Communal Handwashing in Preschools within Accra Metropolis, Ghana. International Journal of Microbiology, 2016, 2617473.

69. THAKADU, O. T., NGWENYA, B. N., PHALADZE, N. A. \& BOLAANE, B. 2018. Sanitation and hygiene practices among primary school learners in Ngamiland district, Botswana. Physics and Chemistry of the Earth, Parts $A / B / C, 105,224-230$.

70. TUDORONIU, C., POPA, M., IACOB, S. M., POP, A. L. \& NĂSUI, B. A. 2020. Correlation of caries prevalence, oral health behavior and sweets nutritional habits among 10 to 19-year-old Cluj-Napoca Romanian adolescents. International Journal of Environmental Research and Public Health, 17, 6923.

71. UBOS. 2016. National Service Delivery Survey-2015 Report [Online]. UBOS Kampala. Available: https://www.ubos.org/wpcontent/uploads/publications/03_20182015_NSDS_report.pdf [Accessed 15th October 2021].

72. UBOS. 2017. The National Population and Housing Census 2014 - Area Specific Profile Series, Kampala, Uganda. [Online]. Kampala, Uganda: Uganda Bureau of Statistics. Available: https://www.ubos.org/wp-content/uploads/publications/2014CensusProfiles/KAMPALA-KCCA.pdf [Accessed 15th October 2021].

73. UNDP. 2021. THE SDGS IN ACTION [Online]. United Nations Development Programme. Available: https://www.undp.org/sustainable-development-goals? utm_source=EN\&utm_medium=GSR\&utm_content=US_UNDP_PaidSearch_Brand_English\&utm_campaign=CENTRAL\&c_src=CENTRAL\&c_src2=GSR\&gclid [Accessed 29-September 2021].

74. UNICEF. 2020. Water, Sanitation and Hygiene in Schools

75. National Standards in Uganda [Online]. Available: https://www.unicef.org/uganda/media/3871/file/Water,\%20Sanitation\%20and\%20Hygiene\%20in\%20Schools:\%20National\%20Standards\%20in\%20Uganı [Accessed].

76. UNICEF \& GIZ. 2013. Field Guide: The Three Star Approach for WASH in Schools [Online]. Available: https://www.unicef.org/kyrgyzstan/reports/fieldguide-three-star-approach-wash-schools [Accessed].

77. UNICEF \& WHO 2020. Progress on drinking water, sanitation and hygiene in school: special focus on COVID-19, UNICEF.

78. UNITED NATIONS. 2015. Transforming our world: The 2030 agenda for sustainable development [Online]. United Nations Department of Economic and Social Affairs Available: https://www.un.org/en/development/desa/population/migration/generalassembly/docs/globalcompact/A_RES_70_1_E.pdf [Accessed 02-October 2021].

79. WAGNER, J. T. \& SAMUELSSON, I. P. 2019. WASH from the START: water, sanitation and hygiene education in preschool. International Journal of Early Childhood, 51, 5-21.

80. WHO 2000. What about boys? A literature review on the health and development of adolescent boys.

81. WHO. 2016. Promoting Oral Health in Africa. Promoting Oral Health in Africa: Prevention and control of oral diseases and noma as part of essential noncommunicable disease interventions [Online]. Available: https://apps.who.int/iris/bitstream/handle/10665/205886/9789290232971.pdf? sequence=1\&isAllowed=y [Accessed].

82. WHO 2019. Surveillance of water, sanitation and hygiene in schools: a practical tool.

83. WHO. 2020. Global School-based Student Health Survey [Online]. World Health Organisation. Available: https://www.who.int/teams/noncommunicablediseases/surveillance/systems-tools/global-school-based-student-health-survey [Accessed 14th October 2021].

84. WHO. 2021. Oral health [Online]. Available: https://www.who.int/news-room/fact-sheets/detail/oral-health [Accessed].

85. WORLD HEALTH ORGANIZATION 2018. Global School-based Student Health Survey Results: 2015-Timor-Leste.

86. YIGZAW, N., AYALEW, G., ALEMU, Y., TESFAYE, B. \& DEMILEW, D. 2021. Observational study on hand washing practice during COVID-19 pandemic among bank visitors in Gondar Town, Northwest Ethiopia. Journal of Human Behavior in the Social Environment, 1-10.

87. ZOU, G. 2004. A modified poisson regression approach to prospective studies with binary data. American journal of epidemiology, $159,702-706$.

\section{Supplementary Files}

This is a list of supplementary files associated with this preprint. Click to download. 


\section{- WASHORALHEALTH.xIsx}

Page 16/16 